\title{
Augmentative and Alternative Communication in South Africa: Accessibility and Implementation
}

\author{
Erna Alant \\ Centre for Augmentative and Alternative Communication \\ Department of Speech Pathology and Audiology \\ University of Pretoria
}

\begin{abstract}
Thispaper deals with the development of a community-based service for the implementation of augmentative and alternative communication (AAC) strategies for people with severely limited verbal expression. The concept of community-based intervention is explained and the process of training as done in the Centre for Augmentative and Alternative Communication (CAAC) is described. Data of pre-and post-training evaluations is discussed as well as follow-up data obtained in the various training contexts. Finally, critical issues related to the follow-up data are discussed.
\end{abstract}

\section{OPSOMMING}

Hierdie artikel handel oor die ontwikkeling van 'n'gemeenskapsgebaseerde diens vir die implementering van Aanvullende en Alternatiewe Kommunikasie (AAK) strategieë vir mense met emstig beperkte ver bale ekspressie. Die konsep van gemeenskap-gebaseerde intervensie word verduidelik en dieproses van opleidingsoos dit plaasvind in die Sentrum vir Aanvullende en Alternatiewe Kommunikasie (SAAK) word beskryf. Data van voor-en na-opleiding evaluering sowel as opvolg inligting verkry binne die verskillende opleidingskontekse, word bespreek. Laastens word sekere kritiese vraagstukke met betrekking tot die opvolg data, uitgelig.

The difficulties involved in sustained use of Augmentative and Alternative Communication (AAC) strategies within the broader community have recently received much attention in the literature (Calculator \& Lucko, 1983; Mirenda, 1992). Various authors have pointed out the limited use of communication boards (Calculator \& Dollaghan, 1982) and gestural and electronic systems in real life situations (Allaire, Gresard et al. 1991). Reasons for failure in using these systems range from client characteristics (for example, no ability to generalize skills), to a stronger environmental emphasis (for example, limited training in significant others' use of the systems), to attitudinal problems of people relating to the disabled and nonspeaking person (Blackstone, 1989; Gorenflo \& Gorenflo, 1991): These authors agree, however, that failure to implement a system can usually be attributed to a combination of factors within the person's environment. Although primary ceregivers are important in the training of AAC strategies, they also need a supportive framework that is conducive to reinforcing the use of the communication systems. The involvement of peers, educational staff and other interested parties is vital to the successful implementation of a communication system (Cumley \& Beukelman, 1992; Van Tatenhove, 1992).

The concerns in South Africa, as in other developing countries, with problems of affordability, equitability, accessiblility and appropriateness of health services, neccessitate a cautious approach when rendering AAC services. Improvement in communication ability has to do with the increase in the quality of life of the individual and cannot be separated from the infrastructure for health and social development within a particular country. This is particularly relevant when addressing issues of technology and sustainability.

The aims of the paper are threefold:

1. to discuss the issue of community-based rehabilitation as a background to the proposed service model

2. to describe the service model used for the implementation of AAC strategies in the Centre for Augmentative and Alternative Communication (CAAC) based at the University of Pretoria, by focussing on the aims and the process used for training

3. to highlight critical issues relating to the follow-up visits to various training contexts.

The concern about making technology more apppropriate for developing countries has become a major issue in the socioeconomic development debate concerning less developed countries. Rifkin and Walt (1986) have identified two schools of thought in relation to the implementation of technology in developing countries. The first maintains that if technology could be successfully implemented, it would transform the society so that a new value system would develop. This approach focusses on the efficacy of interventions and the need to transfer existing technologies as quickly as possible. Intervention models and approaches are emphasized, for example, the centre-based models of AAC (Blackstone, 1989) in which the team of experts evaluate and recommend appropriate intervention strategies within a particular context. The second school of thought holds that the society must evolve in its own way and must therefore develop its own infrastructure for dealing with and using technology. In this way the techno- 
logy would be adapted or changed to suit the particularculture and resources. Technology is effective or appropriate when, within itself, it is an integral part of the development of the society to which it is transferred. This approach focusses on the process through which intervention might be accepted.

This second approach can be described as the Primary Health Care approach, also known as "comprehensive health care" about which Rifkin and Walt (1983, p.560) have the following to say: "Briefly, we see primary health care as being concerned with a developmental process by which people improve both their lives and life-styles. Good health is a key factor to this process." Central to the second approach is the concept of equality, implying accessibility to health services; the need of a multi-sectoral approach to health problems; and community involvement. Snell and Browder (1986) have referred to community-referenced instruction and focus on the philosophy of normalization and applied behaviour analysis. They have stated that normalization assumes the importance of teaching skills for adult life in the community and sets some guidelines for social validation of the results.

According to the second model, AAC implementation can only succeed if integrated within the existing health network and based on active community involvement or participation. This implies that all decision-making and initiative should be taken by the community itself in order to assume responsibility for the intervention procedure as well as for the maintenance of the process. The stress placed on involving significant others in the training of disabled people in the use of AAC strategies emphasizes the importance of understanding and recognizing the infrastructure of the community within which individuals live. The issue is not so much one of introducing people to $\mathrm{AAC}$, as the maintainance and extension of a communication system once it is in use.

The involvement of the community in the decision-making and in the implementation of AAC strategies is thus mandatory. Abrams (1992, p.3) has emphasized this aspect by stating that "the essential element which determines a genuine developmental process is who ultimately makes the decisions". A significant issue, however, revolves around who should constitute the community that is involved. The heterogeneity of opinion within a specific community necessitates the careful description of which people are involved in a particular decision-making context. It is clear that there is need for an infrastructure or network that can reinforce the programme. However, it has been stressed that such infrastructures can not be sustainably developed on their own without all others progressing simultaneously (Abrams, 1992). To use the infrastructure of health seems logical, although Rifkin(1986, p.241) has emphasized that it is not possible to build self-sustaining community participation through health services activities alone. Firstly community participation is a process of changing individual perceptions in the course of time as the dynamics of community members change. Also, when asked what communities want, health services are not necessarily regarded as primary needs. In addition, not many people in the community have had any experience in providing health care and they see little scope for involvement. While the provision of a single-section health service programme (e.g. an immunization programme) often builds credibility, it also limits the possibility of widespread and sustained community participation because these programmes tend to be more specialized in nature. "Community people will gladly accept the benefits, but not as easily accept the responsibility people have expected" (Rifkin 1986, p.243). It is against this background that the introduction of an AAC service model for developing countries becomes interwoven with a very complex set of social networks.
The definition of the term "community" as used in this paper refers to all people involved in the training context, $e . g$. a school or training centre context including, for example, the staff, parents, aides and other interested parties.

\section{THE INTERVENTION MODEL}

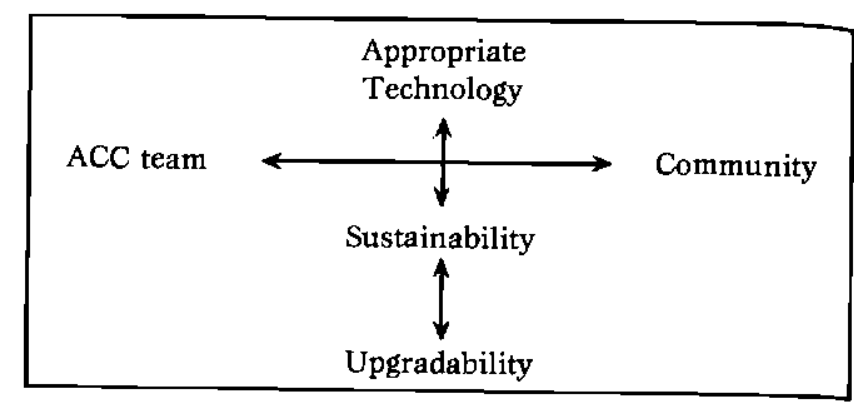

Figure 1: AAC intervention model (adapted from Emmett et al., 1991)

Figure 1 represents the basic components of the AAC service model to be discussed. It centres around making interven. tion and technology an integral part of community participation and decision-making in order to provide a basis for a sustainable service that has some potential for upgradability.

The aims of the project in the CAAC are to evaluate and develop a community-based service for the implementation of AAC strategies for people with limited verbal expression. In this paper, the process used in the CAAC is illustrated in terms of the evaluation of both the training sessions and the changes that took place as observed during follow-up visits within three specific contexts. It is important to emphasize that working with severely handicapped people implies a long-term commitment as most of these clients will need assistance for the rest of their lives. Data presented therefore are those of the initial stages of ongoing interaction with the training contexts.

\section{Process of Training used in the CAAC}

Institutions or individuals approach the CAAC for information relating to AAC strategies. This is followed by an informal visit of CAAC staff to the particular venue. Discussions centre around motivating people to see that "the way things are now, is not the only way they could be" (Hope \& Timmel, 1984, p.4). If a request for training is received, the following steps are followed.

1. A visit to the institution/school or home in order to familiarize the staff with the environment of the trainees and to make a video-tape recording of the children with specific problems to which the CAAC staff should pay special attention during training. The reason for this is that much emphasis is placed on the relevance of training in each context. The language preference of the trainees as well as the clients is determined in order to adjust training to the needs of the context.

2. The trainees are asked to fill in a questionnaire on attitudes and skills/ knowledge of AAC in order to provide some background to the trainers in terms of the level at which training should be directed, as well as to the extent of homogeneity of the group.

3. A one-day training session is held, mostly in situ, focussing on AAC principles and multi-component communication systems. Graphic, gestural and technological systems are introduced (See an example in Appendix 1).

4. After the training sessions an evaluation questionnaire is developed in order to assess the efficacy of the training session 
in terms of knowledge in AAC.

5. Approximately three months after training, the first followup to the training context is done in order to determine the stgtus of trainees regarding the use of AAC. This informal process is aimed at documenting what has occurred within the context since the first visit and at identifying the variables responsible for the occurrence (Meyer \& Janney, 1989; Wacker, 1989). An important additional aim is the identification of needs within the context for further training and support.

\section{Content of Training Programmes}

The primary aim of the training sessions is to expose people to the concept of $\mathrm{AAC}$, multi-component communication and the various ways in which normalization into the community (Snell \& Browder, 1986) can be achieved. Emphasis is placed on a number of issues.

1. The importance of developing an infrastructure for the disabled person within which s/he can communicate. In order to achieve this, no fewer than five people (preferably more) from a particular community have to be selected for any one training session. Everyone in the individual's environment, teachers, aids, friends or caregivers, is encouraged to attend (Cumley \& Beukelman, 1992). During the training session, it is strongly suggested that the trainees establish an AAC interest group within their context in order to establish an organizational structure which would facilitate further regular contact with the CAAC as well as disseminate information on a local level. Various authors (Abrams, 1992; Hope \& Timmel, 1984) have emphasized that the sustainability of development of a service is far more dependent upon organizational capacity than appropriate technology or State support.

2. The purpose of AAC is discussed in terms of two aims: firstly, augmenting verbal interaction in situations where the individual has little or no functional speech; and secondly, using AAC strategies to give entrance into literacy in cases where people cannot read, but will be taught to read in future. This function of AAC strategies is receiving much attention in the international AAC community at present as reflected in the number of papers presented on this topic at the fifth conference of the International Society for Augmentative and Alternative Communication (ISAAC) (1992) in Philadelphia. 3 . In teaching communication, the focus is on facilitating community-referenced skills (Snell \& Bowder, 1986). The usefulness to the individual of what is taught is emphasized in order to facilitate normalization.

4. Much use is made of stories and role-playing (Werner \& Bower, 1982) in order to help trainees act out problem-solving situations similar to those encountered in their own context and in this way to increase the relevance of the teaching context.

\section{DESCRIPTION OF SPECIFIC TRAINING CONTEXT}

Figure 2 provides an analysis of the training contexts used in the data presented in this paper. Three of the contexts are Afrikaans speaking (Welkom, Pretoria and Eersterust) while two contexts are Northern Sotho- and Zulu- speaking (Attridgeville and Mamelodi). All these training contexts were schools for severely handicapped children.

Information given during the training sessions reported on in this paper, centred around the use of graphic symbol systems as most trainees were ignorant of the use of these systems for communication. Due to exposure to the deaf community, most of the trainees had some superficial exposure to gestural systems before. Even so, the main emphasis was on multi-

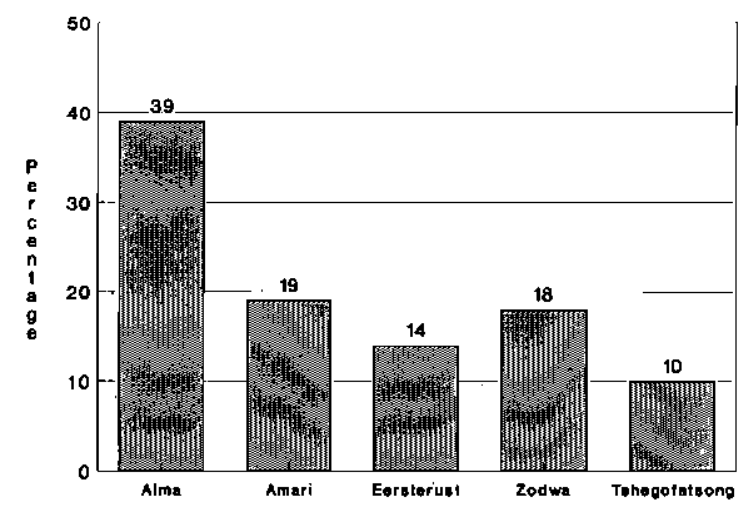

Figure 2: \% Respondents from various schools

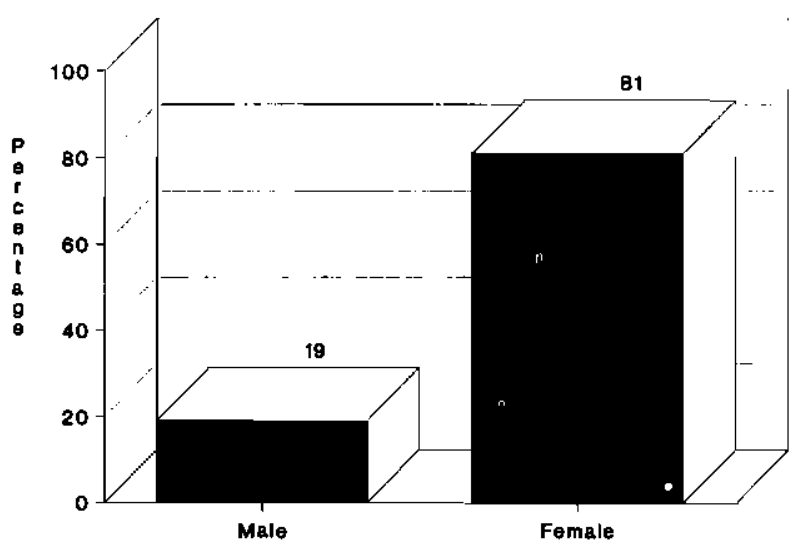

Figure 3: Sex of respondents

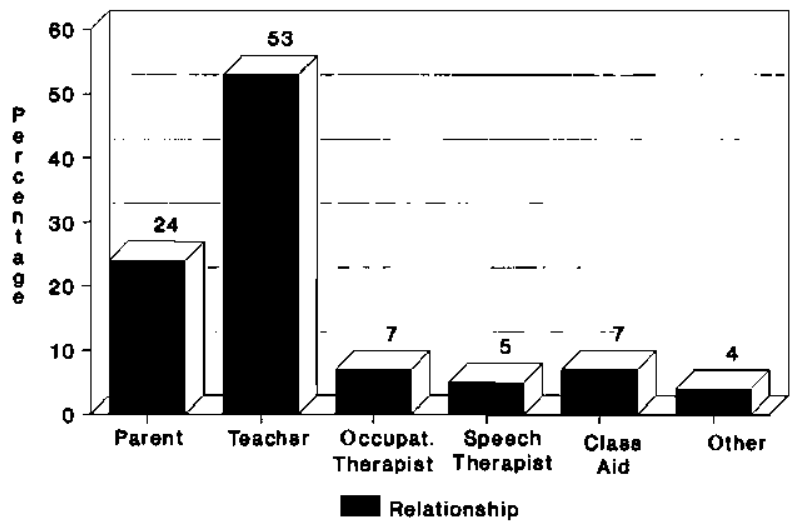

Figure 4: Relationship of respondent to disabled person

component communication, thus emphasizing that the aim is to facilitate communication or to facilitate literacy and not to teach the child "Bliss Symbolics" or any other symbolic system.

\section{Trainee Characteristics}

Most of the trainees in these schools were female teachers, with parents forming the second biggest group (Figures 3 and 4). Although most of the people trained had some form of postmatric training, $18 \%$ of them had only between $8-10$ years at school (Figure 5). It is interesting to note that although the importance of including peers in training sessions is emphasized, none of the contexts have included these participants on an initial training level. This can be attributed to two factors: firstly, to the non-disabled people's need to acquire knowledge about AAC strategies before introducing them to disabled 


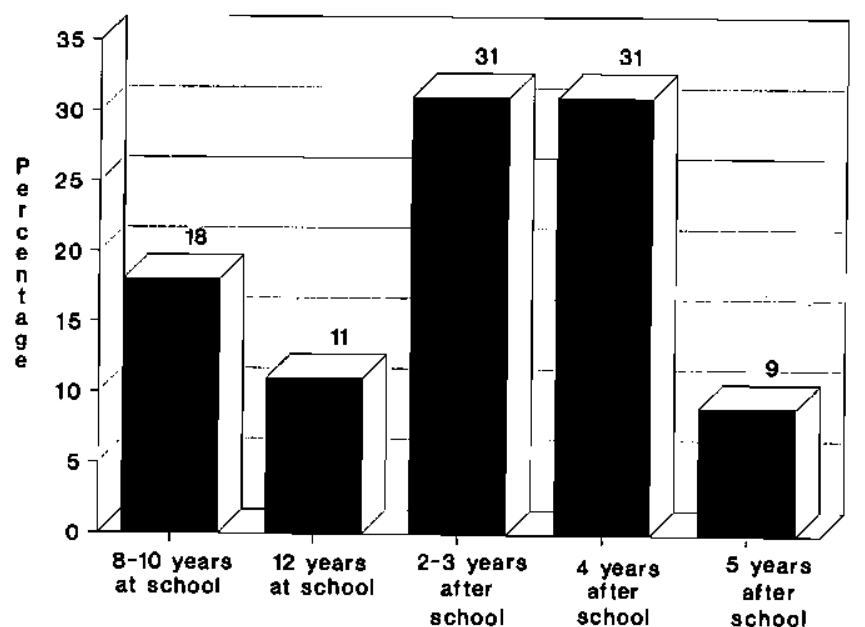

Figure 5: Qualifications of respondents

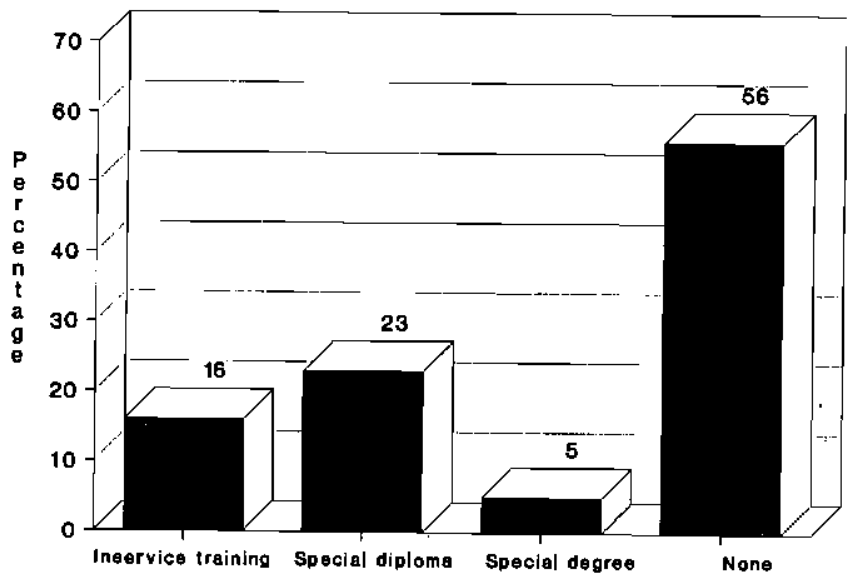

Figure 6: Respondents' special training received

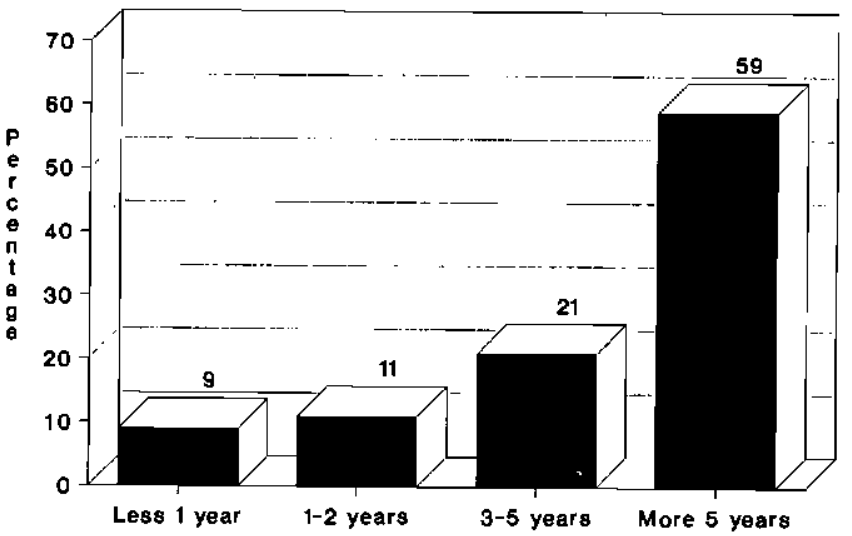

Figure 7: Respondents' exposure time to disabled people

people and peers; and secondly, to the nature of the specific population at these training centres, most of whom are severely cognitively restricted. Fifty six percent of trainees had had no previous training to work with disabled people (Figure 6), although $59 \%$ (Figure 7 ) had been working with disabled people for more than five years.

\section{Pre- and Post- training Evaluations}

Figures 8 to 10 indicate pre- and post- training differences in responses to attitudinal questions towards nonspeaking people and AAC strategies. Although it is acknowledged that attitudes are not changed overnight, these differences in responses reflect an openness to information and training that is a most valuable starting point for intervention. They also indicate that the training provided in the initial stages has made

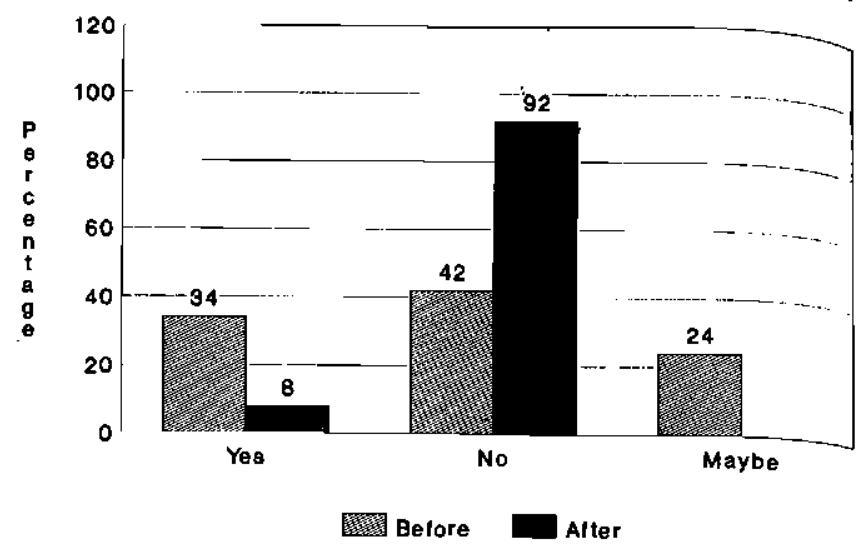

Figure 8: Will using nonverbal means of communication prevent talking?

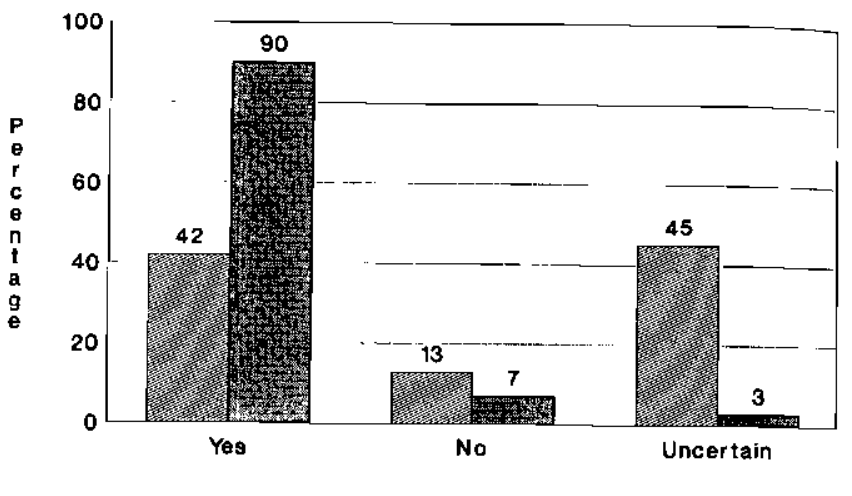

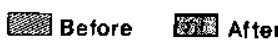

Figure 9: Will people who cannot talk ever learn to read?

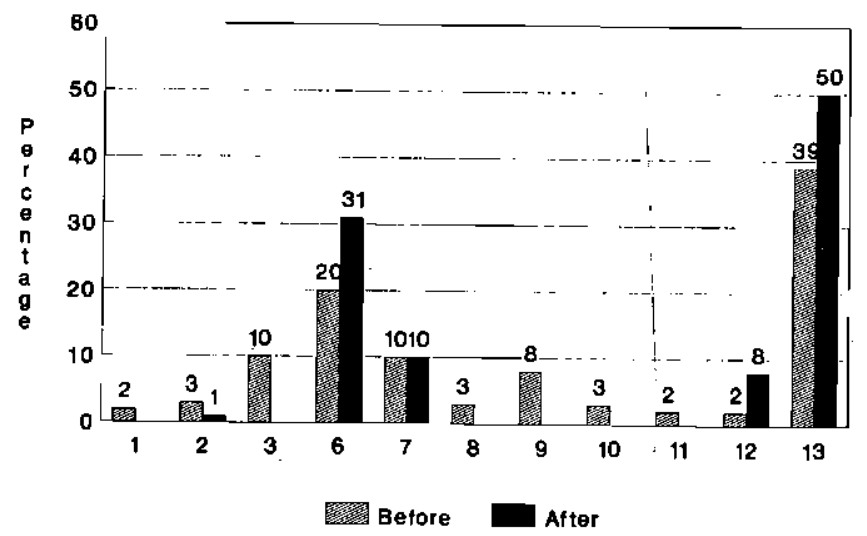

Figure 10: Who should teach disabled people to communicate?

some positive impact on the trainees.

Figures 11 to 14 relate more specifically to the training in graphic symbol systems. Once again, the differences in preand post- training responses are clear and reflect a positive change. Although encouraging in the initial stages of intervention, these results do not guarantee successful intervention. The supportive structure, appropriate knowledge and skills of: all involved as well as the disabled person him-/herself will determine whether this potential for change will manifest 
AAC in South Africa: Accessibility and Implementation

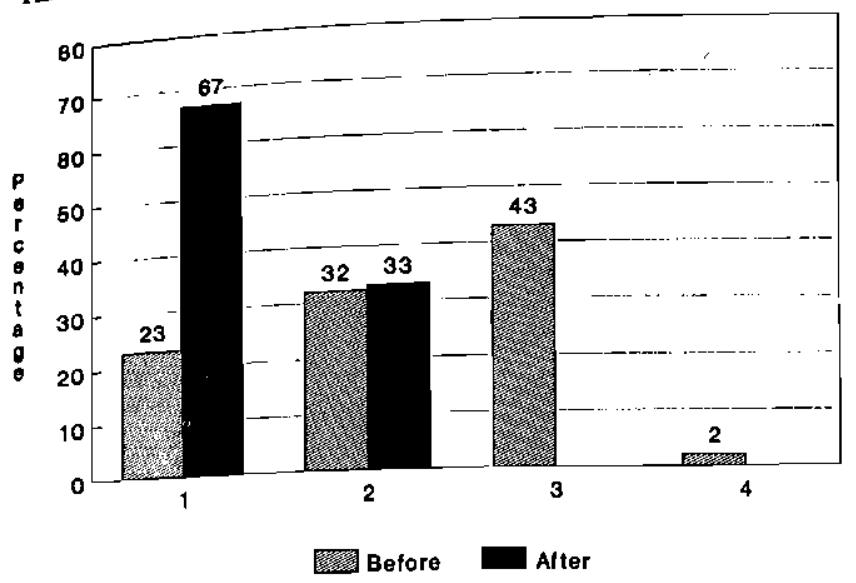

1. Objective : To communicate

2. What : Symbols etc on board

3. Don't know

4. Other

Figure 11: What is a communication board?

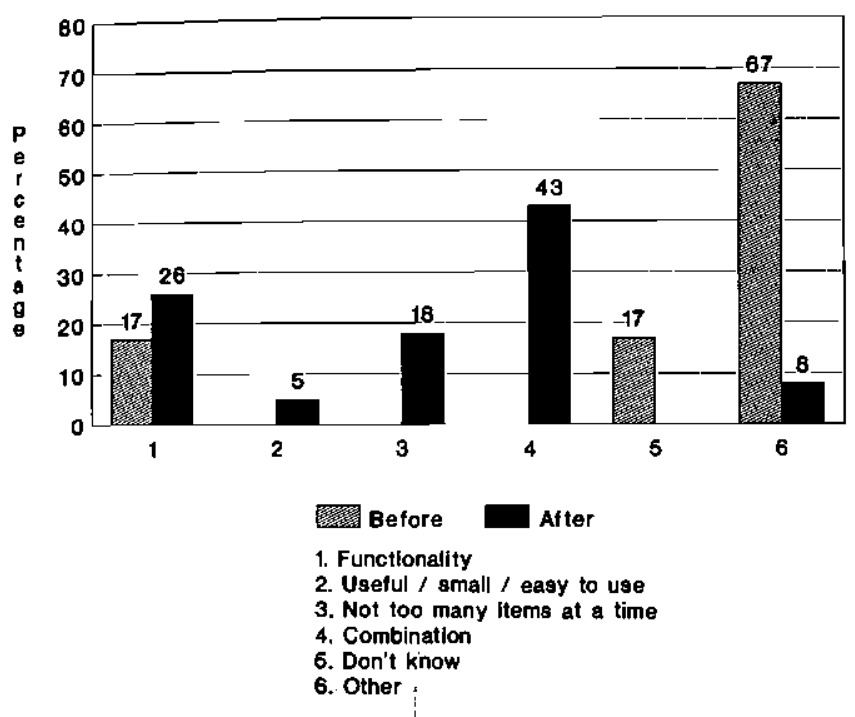

Figure 12: What important features should a communication board incorporate?

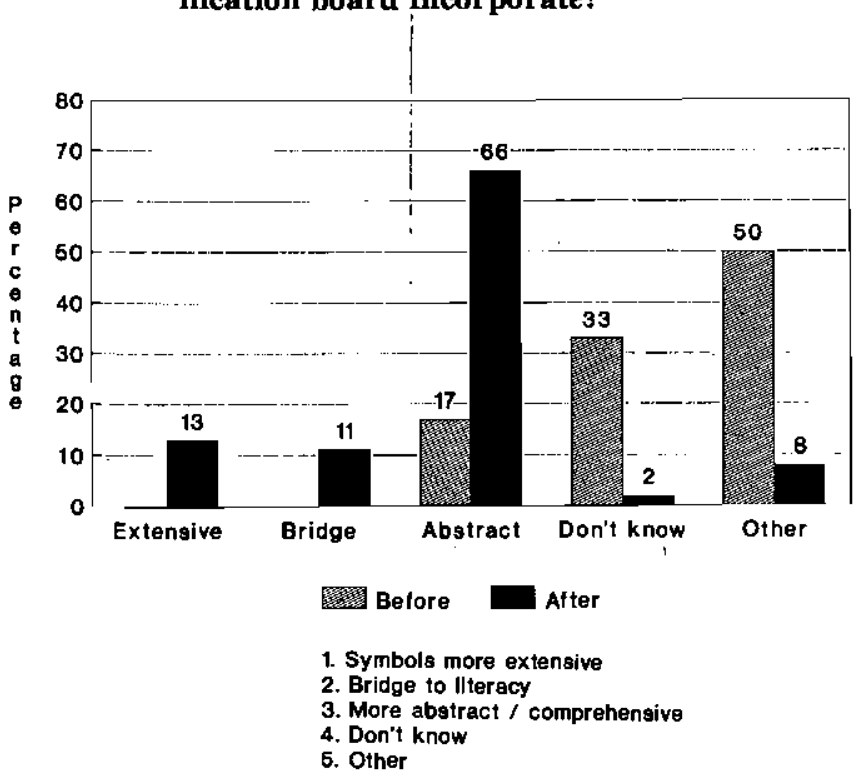

Figure 13: How does a symbol system differ from pictures?

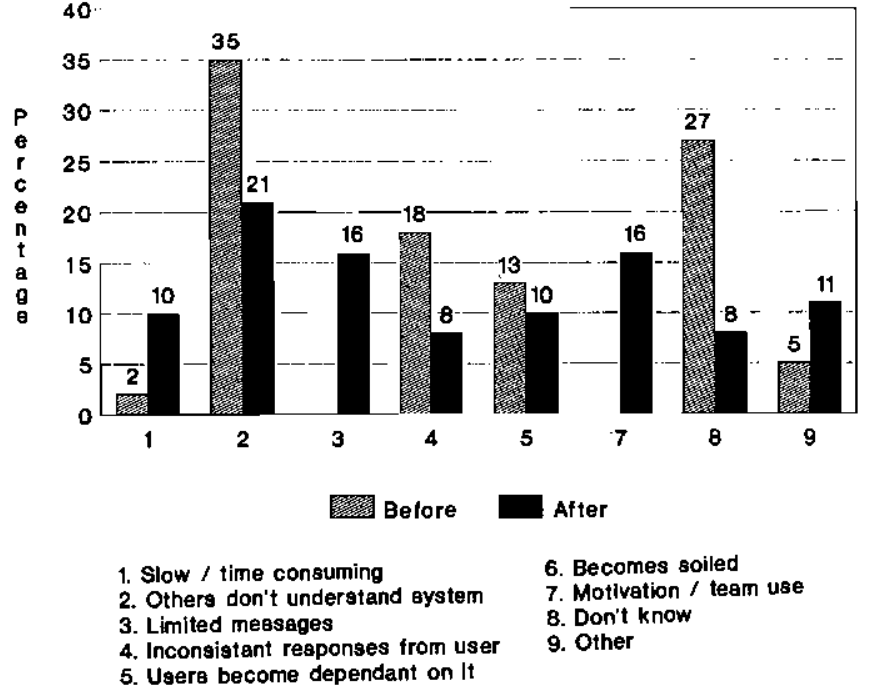

Figure 14: What are the biggest problems in using a symbol system?

\section{Follow-up Data at Three Training Contexts: Discussion of Issues}

Table 1 represents the data after the first formal follow-up visits done by CAAC staff to three of the five contexts in which training took place. Various important issues are highlighted in these observations.

1. All the training contexts had implemented some AAC strategies in the work context. Although the implementation was limited, it was clear that the need for the use of these systems was realized. This response to the initial exposure appears to reflect the intensity of the need experienced by nonspeaking people and their significant others to make contact with each other.

2. Few additional efforts were made to obtain information on AAC or to make contact with other institutions using AAC. In fact, the isolation of institutions working with severely handicapped people and the lack of supporting infrastructure could be seen as a reflection of the fragmentation that characterizes South African communities at present.

3. The extent to which people in the various contexts attempted to make technology suitable for their clients could be related to their general orientation in terms of resources. People who were mainly focussed on using internal resources found it easier to make adjustments for clientse.g Context 1 . Context 2 , however, in which no attempt at making communication technology had been made, was strongly orientated towards external resources with a preference for buying 'ready made' equipment. The fact that there are no financial resources to do this at present therefore limits their efficacy. These differences indicate the heterogeneous nature of communities not only in orientation, but also in terms of empowerment (the ability to take control over one's own life). Context 3 represents a more affluent financial context. What is interesting, however, is that even though the financial constraints may be less, the overall evaluation of AAC and supportive structures are very similar to the other two contexts. Very limited parent contact after the initial training was evident, together with limited implementation. 'The fact that most of the better qualified people were from this institution also made no difference.

Finally, and perhaps the most significant issue in terms of further intervention, is related to the fact that none of the contexts was able to develop an AAC core group or committee to take responsibility for further contact and dissemination of 
Table 1: Follow-up Data of Three Training Contexts

$1=$ Poor $2=$ Average 3 Good

\begin{tabular}{|c|c|c|c|}
\hline $\begin{array}{l}\text { CRITERJA } \\
\text { Potential AAC Clients }\end{array}$ & $\begin{array}{l}\text { CONTEXT } 1 \\
21\end{array}$ & $\begin{array}{l}\text { CONTEXT } 2 \\
12\end{array}$ & $\begin{array}{l}\text { CONTEXT } 3 \\
24\end{array}$ \\
\hline Number of trainees & 14 & 18 & 39 \\
\hline Language & Afrikaans & Northern Sotho & Afrikaans \\
\hline Time laps & 6 months & 4 months & 4 months \\
\hline Present feeling about AAC & 3 & 2 & 3 \\
\hline Attempts at implementation & 3 & 2 & 3 \\
\hline Number of clients introduced & 8 & 3 & 8 \\
\hline $\begin{array}{l}\text { Attempts to obtain additional } \\
\text { information }\end{array}$ & 2 & 2 & 2 \\
\hline $\begin{array}{l}\text { Attempts at making relevant } \\
\text { technology }\end{array}$ & 3 & 1 & 2 \\
\hline Nature of technology & $\begin{array}{l}\text { Boxes for object boards } \\
\text { Books, Pictures, Adapted } \\
\text { switch for tape recorder }\end{array}$ & None & $\begin{array}{l}\text { Communication Boards } \\
\text { Tins }\end{array}$ \\
\hline $\begin{array}{l}\text { Contact with other institutions } \\
\text { using AAC }\end{array}$ & 1 & 1 & 2 \\
\hline $\begin{array}{l}\text { Has an AAC core group been } \\
\text { established? }\end{array}$ & No & No & No \\
\hline $\begin{array}{l}\text { Who are involved in the } \mathrm{AAC} \\
\text { group }\end{array}$ & All teachers & Selected teachers & All who want to participate \\
\hline $\begin{array}{l}\text { Contact with parents after AAC } \\
\text { training session }\end{array}$ & 2 & 1 & 1 \\
\hline $\begin{array}{l}\text { Nature of parent contact at } \\
\text { present }\end{array}$ & $\begin{array}{l}\text { Limited: } \\
\text { Parents work late \& } \\
\text { children stay with } \\
\text { domestic helpers }\end{array}$ & $\begin{array}{l}\text { Parent contact identified } \\
\text { as problem: } \\
\text { They are not involved } \& \text { do } \\
\text { not come to the school }\end{array}$ & Limited \\
\hline $\begin{array}{l}\text { Problems experienced with AAC } \\
\text { implementation at present }\end{array}$ & $\begin{array}{l}\text { Problems identified with } \\
\text { individual children: } \\
\text { no general problems } \\
\text { identified }\end{array}$ & $\begin{array}{l}\text { Teachers not orientated } \\
\text { towards individual } \\
\text { children; } \\
\text { only general problems } \\
\text { identified }\end{array}$ & $\begin{array}{l}\text { Teachers identify their own } \\
\text { problems in class. No gene- } \\
\text { ral problems identified. }\end{array}$ \\
\hline $\begin{array}{l}\text { Nature of problem in } \\
\text { inplementation }\end{array}$ & $\begin{array}{l}\text { Limited expertise } \\
\text { Limited time for } \\
\text { implementation } \\
\text { Too many children in class } \\
\text { Carryover: } \\
\text { parent \& domestic worker } \\
\text { involvement limited }\end{array}$ & $\begin{array}{l}\text { Teachers are not really } \\
\text { orientated towards indivi- } \\
\text { dual children } \\
\text { More class aides needed } \\
\text { Limited parent } \\
\text { involvement } \\
\text { Negative attitudes in } \\
\text { environment } \\
\text { - Guilt } \\
\text { - No interest }\end{array}$ & $\begin{array}{l}\text { Limited expertise } \\
\text { Limited use of switches } \\
\text { Carryover: } \\
\text { limited parent contact } \\
\text { Poor positioning of children } \\
\text { for communication }\end{array}$ \\
\hline $\begin{array}{l}\text { Comments/Impressions of CAAC } \\
\text { team after follow-up interaction }\end{array}$ & $\begin{array}{l}\text { Good participation from } \\
\text { all involved } \\
\text { Non-threatening discus- } \\
\text { sion between CAAC and } \\
\text { participants } \\
\text { Good problem solving deve- } \\
\text { loping between people } \\
\text { Orientated towards inter- } \\
\text { nal resources }\end{array}$ & $\begin{array}{l}\text { Good participation } \\
\text { Much pride in school - little } \\
\text { focus on individual children } \\
\text { Parent contact needed for } \\
\text { rasing funds } \\
\text { Positive attitudes - not } \\
\text { specific to AAC } \\
\text { Strong orientation towards } \\
\text { external resources }\end{array}$ & $\begin{array}{l}\text { Good participation from } \\
\text { people attending } \\
\text { No general problems iden- } \\
\text { tified only individual cases } \\
\text { Group support amongst } \\
\text { staff limited }\end{array}$ \\
\hline
\end{tabular}


information. Although various aspects could be contributing to this, it could be seen as reflecting an insecurity amongst peole in establishing an infrastructure for the ongoing support of AAC strategies. This problem may be consistent with Rifkin's statement (1986) that as few people have had any experience in providing health care (or related therapeutic services) they are unsure whether they can make a meaningful contribution. The development of such an infrastructure obviously demands much more support and effort from all involved in order to ensure that whatever was implemented would be sustained over a long period of time. It could also be a reflection of the complexities involved in the process of commmunity participation as highlighted by Tumwine (1989).

The focus on implementation of AAC strategies could be described as a single section health service because it deals with the implementation of specific communication strategies. Although this could be negative in that it is a specialized intervention process, the emphasis on networking with other social and health contexts as well as sharing responsibility in creating and maintaining these networks would ensure that AAC services would be accessible and meaningful to all those in need. This raises the issue of whether a selective technology approach (for example, focussing on AAC strategies) and a primary health care approach are mutually exclusive concepts as described by Rifkin and Walt (1986). The need for both these approaches is emphasized in the following: "just as much as we have an awareness of the need to alleviate pain and suffering by developing better technical facilitites and more specialized services, so too is there a growing concern about the preponderance of ... infectious diseases that relate to poverty and squalor of a large section of our population" (Alant 1989, p.132). The importance of maintaining and developing specialized treatment and technological advancement can therefore not be disregarded in the process of providing primary health care for all. This suggests a creative interaction between externally-orientated involvement (e.g. the emphasis on technology or specialized treatment) and internally-orientated approaches (primary health care with a strong communitybased focus) in order to develop a humanistic approach towards community-based rehabilitation. A humanistic perspective implies that people become conscious of the alternatives available to them, become motivated to choose and produce the necessary structures to make these alternatives possible.

Community-based rehabilitation is a creative interaction between community members and professionals and is characterized by a process of mutual understanding and respect, vital to any meaningful intervention. Mutual understanding implies ongoing critical appraisal of the models used by both therapist (or developer) and community. Certainly, in the CAAC experience the fundamentals in working with communities lie in the acknowledgement that "the view of the community - how communities view problems and the solutions that make sense are often worlds apart from the views of institutions or professionals" (Grace 1991, p.1) and similarly, that "no conception of development that aims to project solutions onto society can succeed in humanizing society" (Alant 1989, p.132).

\section{ACKNOWLEDGEMENT}

I would like to express my sincere appreciatiion to the CAAC team and the communities who are partners in this process. This research project is funded by the Human Sciences Research Council Programme for Social Affordability.

\section{References}

Abrams, L. J. (1992). Redefining rural development and the emerging role of new development organisations. Paper presented to Standing Committee for Water Supply and Sanitation. Johannesburg.

Alant, C. J. (1989). Development and health care: Some sociological comments. In C. J. Alant (Ed.), Sociologys and society. Johannesburg Southern Books.

Allaire, J., Gresard, R., Blackman, T. \& Hostler, S. (1991). Children with severe speech impairment: Caregiver survey of AAC use Augmentative and Alternative Communication, 7, 248 - 255 .

Bjaras, G., Haglund, B. \& Rifkin, S. (1991). A new approach to community participation. Health Promotion International, 6(3), 199 206.

Blackstone, S. (1989). Augmentative communication services in the schools. Asha, 1, $61-64$.

Calculator, S. \& Dollaghan, C. (1982). The use of communication boards in a residential setting. Journal oi Speech and Hearing Disorders, 14, 281-287.

Calculator, S. \& D'Altilio-Lucko, C. (1983). Evaluating the effectiveness of a communication board training program. Journal of Speech and Hearing Disorders, 48, 185-192.

Cumley, G. \& Beukelman, D. (1992). Roles and responsibilities of facilitators in AAC. Seminars in Speech and Language, 13(2), $111-119$

Emmett, A. B., Phillips, H. \& Barendse, B. (1991). Social and economical aspects of water provision and sanitation in developing areas. Pretoria Human Science Research Council Publisher.

Gorenflo, C. W. \& Gorenflo, D. W. (1991). The effects of information and augmentative communication technique on attitudes towards nonspeaking individuals. Journal of Speech and Hearing Research $34,19-26$.

Grace, H. (1991). Views from the tugboat. Unpublished material ртеsented at the Kellogg Seminar, South Africa.

Hope, A. \& Timmel, S. (1984). Training for transformation. Mambo Press: Gweru.

Meyer, L. \& Janney, R. (1984). User-friendly measures of meaningful outcomes: Evaluating behavioral interventions. Journal of the Association for Persons with Severe Handicaps, 14(4), $263-270$.

Mirenda, P. (1992). School to postschool transition planning for AAC users. Seminars in Speech and Language, 13(2), $130-142$.

Rifkin, S. (1986). Lessons from community participation in health programmes. Health Policy and Planning, 13, $240-249$

Rifkin, S. \& Walt, G. (1986). Why health improves: Defining the issues concerning 'comprehensive primary health care' and 'selective primary health care'. Soc. Sci. Med.. 23(6), $559-566$

Snell, M.\& Browder, D. (1986). Community-references instruction. Journal of the Association for Persons with Severe Handicaps, 11(1) 1 - 11 .

Tumwine, J. (1989). Community participation as myth or reality: A personal experience from Zimbabwe. Health Policy and Planning. $4(2), 157-161$.

Van Tatenhove, G. (1992). Using competent AAC users as peer trainers. Paper delivered at the fifth conference of the International Society for Augmentative and Alternative Communication, Philadelphia

Wacker, D. (1989). Introduction to special feature on measurement issues in supported education: Why measure anything? Journal of the Association for Persons with Severe Handicaps, 14(5), 254.

Werner, D. \& Bower, B. (1982). Helping health workers learn. Gwero: Mambo Press.

White, O. R. (1988). Probing skill use. In N. Haring (Ed.), Generalization for students with severe handicaps: Strategies and solutions. Seattle: University of Washington Press. 
APPENDIX 1

\section{LAUDIUM}

24 June 1992

ONE DAY COURSE: INTRODUCTION TO AUGMENTATIVE AND ALTERNATIVE COMMUNICATION

\section{PROGRAMME}

Aim: To expose staff and parents to the use of AAC systems in teaching and communication. The purpose of this session is to introduce people to the concept of AAC. This initial course will not be adequate preparation for the implementation of AAC strategies. Further support for implementation will be necessary.

Objectives:

- To give a summary of why AAC strategies are important for use with severely disabled people

- To identify the different problems relating to communication with severely disabled children

- To discuss briefly different symbolic and gestural systems

- To discuss certain ways of implementing these systems in a school and home context

- To discuss the importance of the establishment of an AAC core group in Laudium to ensure further follow-ups and exchange of information between CAAC and the Laudium Centre staff and parents.

Time Schedule:

08.00

08.30-09.30:

09.30-10.30:

10.30-11.00:

11.00-11.30:

11.30-12.30:

12.30-13.00:

\section{Registration}

Introduction: What is Augmentative and Alternative Communication (AAC)?

Problem statement: What are the problems confronting us when working with the severely disabled person?

What can be done about these problems? Roleplay

TEA

How can these strategies be implemented? The importance of establishing a core group for AAC at the Centre

Filling in of evaluation questionnaire 